\title{
Mapping Natural Hazard Impacts on Road Infrastructure-The Extreme Precipitation in Baden-Württemberg, Germany, June 2013
}

\author{
Sina Keller • Andreas Atzl
}

Published online: 19 September 2014

(C) The Author(s) 2014. This article is published with open access at Springerlink.com

\begin{abstract}
Infrastructures in Europe have been affected by impacts of extreme natural events with increasing frequency over the past decades. One of the most recent examples is the flooding that affected parts of Germany in June 2013. Global warming is expected to change patterns of climate-related extreme events affecting infrastructure. This article presents an explanatory approach. Based on an observational design, causal connections between the occurrence and patterns of extreme events and related road infrastructure impacts are analyzed. The hazard mapping case study in the state of Baden-Württemberg combines traffic information and data on the June 2013 extreme precipitation in Germany. It examines the precipitation occurrence and road infrastructure impact characteristics in Baden-Württemberg and identifies spatiotemporal hazard patterns. The article suggests further research needs and fields of application for risk mapping in climate change adaptation research in Germany.
\end{abstract}

\section{Keywords Extreme}

precipitation · Floods · Germany · Hazard

patterns $\cdot$ Landslides $\cdot$ Road infrastructure

\section{Introduction}

Natural disasters with long-term effects on infrastructure have been rare in southwest Germany over the past dec-

S. Keller $(\square) \cdot$ A. Atzl

Institute of Regional Science/Institute of Urban and Regional Planning, Karlsruhe Institute of Technology, Kaiserstraße 12, 76131 Karlsruhe, Germany

e-mail: sina.keller@kit.edu ades. Compared to other countries, the World Risk Index (Welle et al. 2013) of Germany is very low due to a lower degree of susceptibility and exposure to extreme events and a higher degree of adaptive and coping capacity. In the Global Climate Risk Index (Kreft and Eckstein 2013), Germany ranks 32nd out of 178 countries. According to Kreft and Eckstein (2013), this ranking is mainly the result of the 2003 European heat wave. However, challenges for disaster management in Germany arise from global changes of natural processes. It is highly probable that climaterelated extreme events will increase in frequency and magnitude in the future (Braubach 2011). The Intergovernmental Panel on Climate Change (IPCC) expects future extreme events to "produce large impacts on infrastructure" (IPCC 2012, p. 248). Infrastructure strongly influences the extent to which natural processes and hazards turn into disasters. Urban centers in Germany rely on the existence and availability of infrastructure systems (Atzl et al. 2012).

Large parts of the present-day infrastructure systems in Germany were planned and constructed in decades without major changes in the frequency and magnitude of extreme events. As a result, for example, flood prevention in Germany mainly relies on past experiences with extreme events to calculate the $\mathrm{HQ}_{100}$-value for a one-hundred-year flood (Wagner 2010). This is illustrated by a discussion in Germany whether or not the early June 2013 flood should be perceived as a rare event (Etscheit 2013). This and other events like hurricanes Lothar in 1999 and Kyrill in 2007 (Schramm 2007), the 2005 snow chaos in the West German Münsterland region, or the 2003 heat wave have shown the potential negative effects of extreme events on infrastructure (John-Koch and Fekete 2010) and the need to consider potential negative climate change impacts on infrastructure systems to avoid future disasters. 
Interviews conducted by the authors with transport infrastructure experts have shown a need for specific expertise particularly on the causal connections between risks for infrastructure systems and the underlying causes in the natural and social systems. Only recently, the German Federal Highway Research Institute (BASt) has started projects to assess climate change impacts on federal highways (Auerbach et al. 2014). The majority of these projects analyze potential causal connections between climate parameters and infrastructure through experimental designs for specific infrastructure components such as bridges or tunnels, and for specific building materials such as concrete or asphalt. These techno-analytical approaches are valuable contributions to understanding the impacts of extreme events on road infrastructure. However, in interviews, experts involved in these projects have stated the difficulty to clearly identify the actual connections between climate patterns and infrastructure damage due to the multiplicity of potential independent variables. For example, road deformation may result from a combination of increasing temperatures, but also from higher traffic volume or decreasing bitumen quality.

In this article, the authors present an explanatory approach. Based on an observational design, causal connections between the occurrence and spatiotemporal patterns of extreme events and infrastructure impacts should be explained. Using secondary data on actual events, this approach provides a different perspective and complements the experimental research conducted in other projects. The present hazard mapping case study combines traffic information and data on the extreme precipitation that occurred in Germany in early June 2013. ${ }^{1}$ It focuses on the hazard effects in the state of Baden-Württemberg, where more than 100 hazardous incidents occurred within a few days.

The case study is based on a systemic framework for the assessment of infrastructure risks introduced by Atzl and Keller (2013). The framework differentiates between three systemic constituents: the critical infrastructure, its natural environment, and its social environment, all of which interact (Atzl and Keller 2013). To facilitate the analysis of causal connections across systems and sectors, existing concepts and definitions of natural processes, hazards, and disasters are applied to this systemic framework.

Critical infrastructure "includes technical and organizational multi-level structures which are crucial for the maintenance of functions in their social environment" (Atzl and Keller 2013, p. 31). Thus, critical infrastructure is a key factor in the occurrence or avoidance of disasters. While maintaining societal functions, critical infrastructure is regulated by institutions and individuals in the social

\footnotetext{
${ }^{1}$ Extreme precipitation started in late May 2013, but most impacts in Germany occurred in June.
}

environment (Atzl and Keller 2013). Regulation is the result of normative processes that lead to priorities and policies of societal institutions (Fürst 2011; Moss 2011; Atzl and Keller 2013). Critical infrastructure is framed by conditions of its natural environment. Today, natural processes are often influenced by humans (Becker et al. 2006). However, the analysis of dynamic systems needs a starting point, in this case processes in the natural environment that influence the conditions of road infrastructure functionality. ${ }^{2}$

Section 2 applies existing concepts of natural processes, natural hazards, and natural disasters to the systemic framework. This facilitates the understanding of causal connections across natural, infrastructural, and social systems. Section 3 provides an overview of the case study, the used data sources and the data processing steps. Section 4 maps the extreme precipitation in early June 2013 and its impacts on the road infrastructure in Baden-Württemberg, and identifies spatiotemporal hazard patterns. Section 5 discusses the results and limitations of this study, and outlines further research needs. Section 6 gives an outlook on possible fields of application for risk mapping in climate change adaptation research in Germany.

\section{Natural Processes, Hazards, and Disasters: Crossing Borders of the Natural Environment System}

The United Nations International Strategy for Disaster Reduction (UNISDR) defines disaster as an event that is concentrated in space and time, breaks down social structures, and disrupts essential social functions (UNISDR 2009). From an interdisciplinary, systemic perspective (Ropohl 2012), disasters result from complex interactions between three major systems: the natural environment, the social environment, and the built environment, including infrastructure systems (Burton et al. 1993; Atzl and Keller 2013).

\subsection{The Natural Environment}

The natural environment is a system that includes the components of topography, climate, landforms, soil, and vegetation. Each component is composed of elements such as temperature, precipitation, and elevation. The essential climate elements of air pressure, air temperature, air humidity, cloudiness, and precipitation characterize specific climate or weather combinations in locations on

\footnotetext{
2 The systemic concept focuses on critical infrastructure. The present case study includes all road infrastructures in Baden-Württemberg. The criticality assessment of other infrastructures is important, but goes beyond this article's scope.
} 


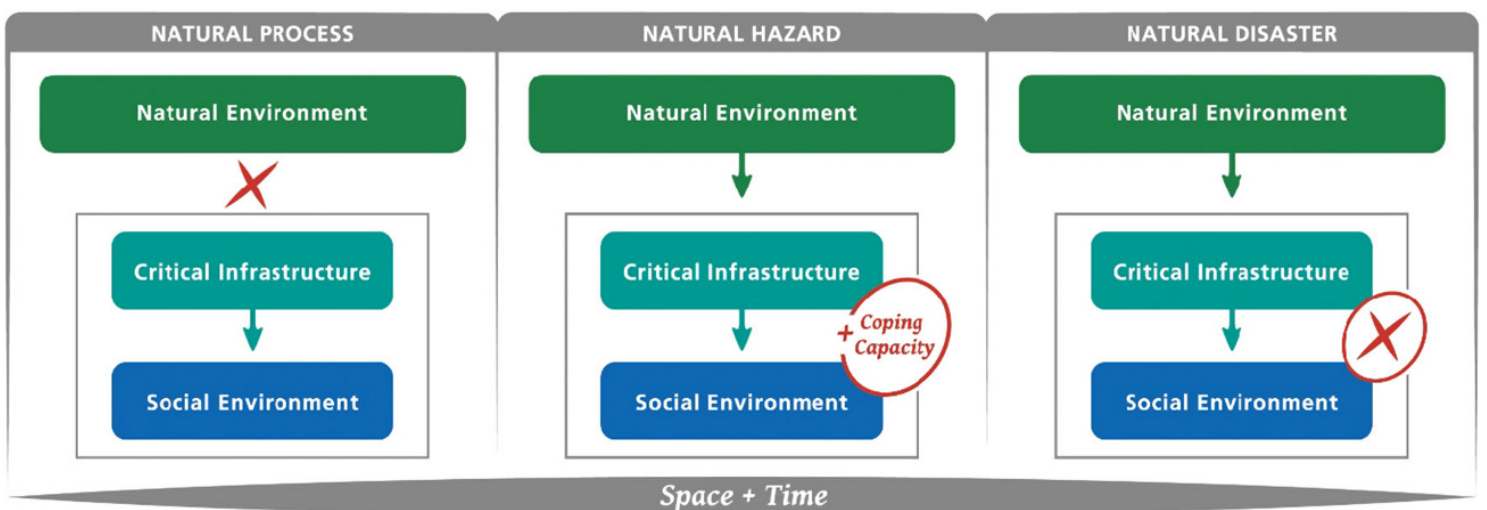

Space + Time

Fig. 1 Characteristics of natural process, natural hazard, and natural disaster

different spatial scales (Burton et al. 1993; Gares et al. 1994; Temesgen et al. 2001).

The system's elements are interdependent (Mitchell et al. 1989). Every change in one of these elements directly affects the others (Minciardi et al. 2006). As a consequence, the complex natural system changes its structure and conditions over time (temporal scale) and space (spatial scale). Because these scales interfere, Massey (1999, p. 264) refers to "space-time" as an inseparable entity.

Conditions of the natural environment are defined by processes taking place within the system. These processes can have positive effects on natural environment functions (White et al. 2001; European Environment Agency 2003). But natural processes may also negatively affect infrastructure and the social environment (Mitchell et al. 1989; Geipel 1992), and cause natural hazards and disasters. Peterson et al. (2008, p. 1) state that "changes in weather and climate extremes can have considerable impacts on" the transportation sector. Extreme temperatures can cause road surface damages and increase road maintenance costs. Increasing precipitation intensity leads to flooded roads. Besides road infrastructure damages, the changing hazardous weather conditions affect the road traffic flow (Edwards 1999). Hydroplaning risks involving a potential loss of vehicular control in particular create severe road conditions for drivers.

\subsection{From Natural Processes to Hazards and Disasters}

Changing natural processes do not necessarily entail hazards or disasters. As Weichselgartner (2001, p. 86) emphasizes, "the disaster itself occurs within society, not within nature." Natural hazards and disasters are natural processes that cross system borders, always affecting systems relevant to humans. The arrows in Fig. 1 (middle and right box) illustrate this cross-system character of natural hazards and disasters. As Weichselgartner (2001, p. 86) states: "A flood in a non-settled polar region or a volcano eruption on a non-colonized island we would hardly call a natural disaster." Only under certain conditions, natural events can evolve into natural hazards and disasters (Plate and Merz 1993; Alcántara-Ayala 2002).

As the cross in Fig. 1 (left box) illustrates, natural processes are inherent and limited to the natural environment system. Although natural processes can be induced by human or natural mechanisms, they are regarded as part of the natural environment and include primarily physical factors (Gares et al. 1994; Sherman and Nordstrom 1994). As long as their impacts are limited to the natural environment system, they do not constitute a threat for humans and infrastructures.

Natural hazards arise from natural processes with negative impacts on the social or infrastructure system (Gares et al. 1994; Temesgen et al. 2001; Felgentreff and Glade 2008; Eiser et al. 2012). Natural hazards comprise physical events converted into a threat by "conditions of exposure and vulnerability" (IPCC 2012, p. 31). Sherman and Nordstrom (1994, p. 264) define natural hazards as processes "that occur in the natural system [and] become hazards when they threaten to impinge on human resources." In case of natural hazards, these can, to a certain extent, be absorbed by critical infrastructure systems. The same applies to the social environment, which is able to cope with negative impacts up to an acceptance level defined by normative processes (Atzl and Keller 2013). Figure 1 (middle box) illustrates the connection between the natural environment system and the two other systems through a directional arrow. The capacity of either the infrastructure or the social system to cope with a natural hazard is symbolized by the red circle.

In contrast, natural disasters are natural hazards that severely and negatively alter the functionality of the social environment or infrastructure (Alcántara-Ayala 2002; IPCC 2012). Natural disasters occur if the social 
environment or infrastructure systems are unable to cope with a natural hazard. Sobiech $(2013$, p. 50) states that "a disaster results from interactions between [...] hazards and vulnerable conditions of the [...] system." Thus, a natural disaster consists of two elements: the causing natural processes and their impacts on vulnerable systems (Mitchell et al. 1989; Plate and Merz 1993; Felgentreff and Glade 2008). The vulnerability of infrastructures and the social environment is reduced by their capacity to cope with negative impacts. A lack of coping capacity may turn a natural hazard into a natural disaster (Temesgen et al. 2001; Felgentreff and Glade 2008). Figure 1 (right box) illustrates the lack of coping capacity by replacing the coping capacity with a cross. Today's high degree of infrastructure reliability in Germany decreases the social acceptance of disturbances. People are used to and expect infrastructure systems to work. They do not expect longer lasting interruptions (Lorenz 2010; Deutscher Wetterdienst 2011). This phenomenon is referred to as the "vulnerability paradox" (Deutscher Bundestag 2011, p. 17). This paradox leads to decreased individual preparedness of the population and lower coping capacity of the overall social system towards unexpected events. Spatial and temporal changes of the natural environment can lead to a change of natural processes and coping capacity within the systems. Therefore, the appearance of a natural process as a hazard or disaster depends on the specific conditions within spacetime.

\section{Case, Data Sources, and Methods}

This section starts with an introduction of the case of the June 2013 extreme precipitation in Baden-Württemberg, Germany. It then presents an overview on the data sources that have been used for this study and the steps to process the data for the analysis.

\subsection{The Case of the June 2013 Extreme Precipitation in Baden-Württemberg}

The state of Baden-Württemberg is located in southwest Germany (Fig. 2) and characterized by two major landscapes: (1) the South German Scarplands with the Upper Rhine and Neckar Plains, and the low mountain ranges of the Black Forest and Swabian Alb; and (2) the Alpine foothills southeast of the Danube River. These major landscapes feature a variety of landscape subtypes. Due to the scarplands, the geological setting in Baden-Württemberg is heterogeneous with frequently changing bedrock (Brodbeck 2012). Weather-resistant rocks like sandstone and Muschelkalk alternate with softer layers like marlstone (Gebhardt 2008; Brodbeck 2012). Particularly in the northeastern part of Baden-Württemberg, the marlstone is clayey with a high swelling capacity that increases landslide risks (Gebhardt 2008).

Urban centers such as Stuttgart, Karlsruhe, and Mannheim with highly developed industry and service sectors make Baden-Württemberg one of the strongest economic regions in Europe (Atzl and Keller 2013). The state possesses a dense network of road, railway, and water transport infrastructures with important corridors for the TransEuropean transport network (Gebhardt 2008).

In early June 2013, a devastating flood hit large parts of Germany. Although Baden-Württemberg was among the less severely affected German states, extreme precipitation led to interruptions and damages of roads, houses, and other buildings. A combination of different natural processes caused this flood. Meteorological preconditions, such as an above-average duration of winter with frost and abnormal precipitation rates in April and May 2013, led to oversaturated soils in large parts of Germany, reducing the infiltration of water (Schröter et al. 2013).

A stable weather condition called "low Middle Europe" (Tief Mitteleuropa, translation by authors) induced this extreme precipitation of 22.75 trillion liters over Germany in 4 days. Two low-pressure areas and spring runoff in the Alps triggered the initial hazard situation in Germany (DWD 2013; Schröter et al. 2013).

\subsection{Data Sources and Processing}

Two datasets were applied for a case study period of one week from 28 May to 3 June. The first dataset includes precipitation data and was provided by the German Weather Service (in the following referred to as "DWD REGNIE dataset 2013") (DWD 2011). The second dataset includes all weather-related traffic reports for BadenWürttemberg and was provided by the traffic information service of the Baden-Württemberg state police (in the following referred to as "IMBW dataset 2013"). Table 1 shows the details of both datasets.

The precipitation data came in a raster format and were interpolated at a regional scale of a $1 \mathrm{~km}^{2}$ grid. The interpolation method REGNIE, used by the German Weather Service, considers geographic longitude, latitude, altitude as well as direction and absolute value of the exposition (see Table 1). The provided data represent the average daily precipitation rate calculated in $1 / 10 \mathrm{~mm}$. The grid consists of 611 grid points in West-East direction and 971 grid points in North-South direction. In a geographic information system, the raster data were projected in the Gauss-Krüger net referring to the 9th degree East meridian and clipped to the extent of the State of Baden-Württemberg. The Gauß-Krüger projection is used for Germany since it refers to a transversal Mercator projection. Based 
Fig. 2 Spatial pattern of the state of Baden-Württemberg, Germany. Source Map by authors based on Esri (Environmental Systems Research Institute), 2005. Data and Maps Dataset (in the following referred to as "Esri dataset 2005")

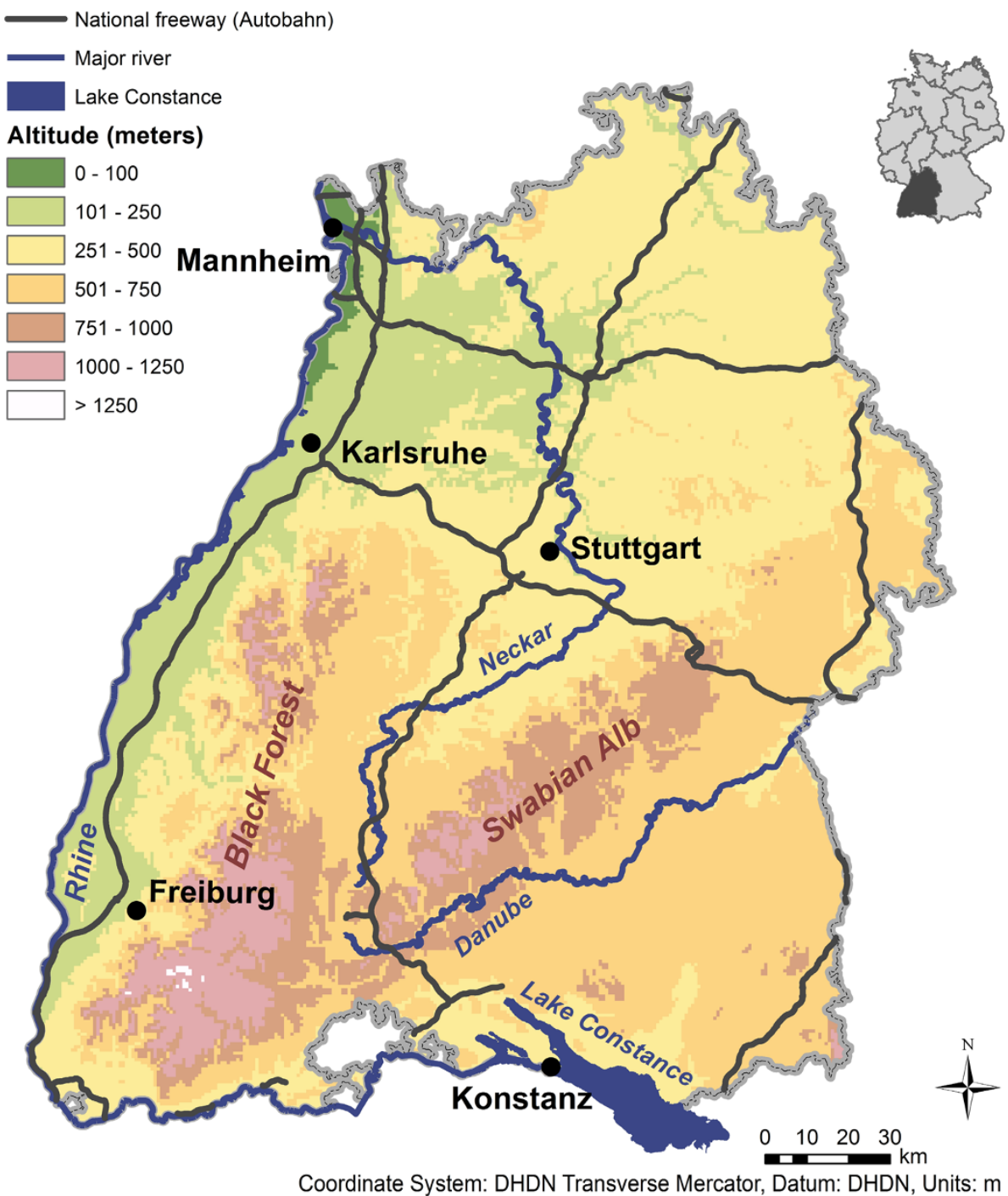

on this specific Mercator projection is the georeference model of the Bessel Ellipsoid. Finally, precipitation rates were plotted for single days and for the entire case study period (Figs. 4 and 5) and classified into 16 equidistant categories.

The traffic information service of the Baden-Württemberg state police provides radio stations and other media outlets with frequently updated traffic information. Longerlasting traffic disturbances are re-announced regularly until the situation is solved. The dataset used here includes all weather-related traffic warnings and announcements that were published between 28 May 2013 at 0.00 a.m. and 3 June 2013 at noon. The dataset comprises a table with more than 50 text announcements. They include information about the traffic situation or warning, the affected road and road sections, as well as the announcement publishing date and time.

The first step in preparing this information for the analysis was to manually merge redundant announcements with different publishing times, give them a unique key variable, and record the first and the last announcement date and time. Based on this, the duration of every traffic disturbances is calculated. In a second step, general weather warnings without a specific spatial reference were deleted from the dataset. Based on the text description, each incident was manually classified by road incident type (disturbance, partial or complete closure) and a road incident cause (hydroplaning, flooding/flooding risk, landslides/landslide risk, and others). In the case of landslides and flooding, actual events and the risk of events are merged in one category. The reason is that the announcements were not always explicit whether a flooding or landslide had already occurred on the road, whether it had occurred next to it or whether there was just a higher risk of occurrence for the area in general.

In the next step, the affected road section for every announcement was clipped from a GIS layer of the BadenWürttemberg road network and given the same key 
Table 1 Dataset description

\begin{tabular}{|c|c|c|}
\hline & Precipitation data & $\begin{array}{l}\text { Weather related traffic } \\
\text { reports }\end{array}$ \\
\hline $\begin{array}{l}\text { Data } \\
\text { source }\end{array}$ & $\begin{array}{l}\text { Provided by the German } \\
\text { Weather Service }\end{array}$ & $\begin{array}{l}\text { Provided by the traffic } \\
\text { information service of the } \\
\text { Baden-Württemberg state } \\
\text { police }\end{array}$ \\
\hline $\begin{array}{l}\text { Data } \\
\text { format }\end{array}$ & Raster format & $\begin{array}{l}>500 \text { redundant, non- } \\
\text { geocoded text messages in } \\
\text { a table }\end{array}$ \\
\hline Method & $\begin{array}{l}\text { Interpolation method } \\
\text { REGNIE considers } \\
\text { geographic longitude, } \\
\text { latitude, altitude as well as } \\
\text { direction and absolute } \\
\text { value of the exposition } \\
\text { (see DWD 2009) }\end{array}$ & $\begin{array}{l}\text { Manual verification, } \\
\text { summary, and clearing } \\
\text { Manual classification } \\
\text { according to incident } \\
\text { cause and type } \\
\text { Manual geocoding into the } \\
\text { road network of Baden- } \\
\text { Württemberg }\end{array}$ \\
\hline Values & $\begin{array}{l}\text { Precipitation raster dataset } \\
\text { is calculated following the } \\
\text { REGNIE (regionalization } \\
\text { of precipitation totals) } \\
\text { method by the DWD. This } \\
\text { method calculates "the } \\
\text { spatial compensation of } \\
\text { current daily, monthly and } \\
\text { yearly precipitation } \\
\text { distributions" (DWD } \\
2009 \text {, p. 2). As reference } \\
\text { data regionalized } \\
\text { precipitation values of the } \\
\text { reference period } 1960 \text { to } \\
1990 \text { are used } \\
\text { Temporal resolution: } 1 \text { day } \\
\text { Spatial resolution: } 1 \mathrm{~km}^{2} \\
\text { grid }\end{array}$ & $\begin{array}{l}\text { Length of an incident } \\
\text { represents the maximum } \\
\text { traffic disturbance or road } \\
\text { closure per day }\end{array}$ \\
\hline
\end{tabular}

variable as in the announcement. The clipped road incident sections were then exported into a road incident layer. Finally, the road incident layer was, based on the key variable, merged with the traffic announcements table to visualize the maps with road incident types and causes. The precipitation data and the traffic data were combined in a GIS and visually analyzed.

For the statistical analysis the total hourly number of road incidents from 28 May to 3 June 2013 was combined with the average daily precipitation rate. Section 4.1 gives detailed information about the statistical analysis.

\section{Results}

This section presents the results of the analysis of the case study on extreme precipitation in Baden-Württemberg. First, the temporal hazards patterns are described by a fundamental statistical analysis. Second, the spatiotemporal change of hazard patterns is mapped. Final, the clarification of the spatiotemporal patterns of the mapping follows by characterizing the natural hazards.

\subsection{Description of Temporal Hazard Patterns}

Figure 3 provides an overview of the case study's temporal patterns by combining a red scatter plot of the number of road incidents per hour with grey box plots of the average daily precipitation rate in the time period from 28 May to 3 June 2013. The ends of the whisker define the minimum and maximum daily precipitation rate in $\mathrm{mm}$. The bottom and top of the grey box represent the first and third quartile, the band inside the box the median, and the triangles the arithmetic mean. Depending on the definition, days with precipitation rates exceeding 20,35 , or $84.9 \mathrm{~mm}$ are defined as extreme precipitation days (Bender and Schaller 2012). The mentioned thresholds are defined by the precipitation intensity and amount. For Germany, the precipitation rates exceeding $35 \mathrm{~mm}$ per day (criteria by Schimpf) and $84.9 \mathrm{~mm}$ per day (criteria by Wussow) are regarded as extreme (Bender and Schaller 2012). A precipitation rate exceeding $20 \mathrm{~mm}$ per day is a criterion defined among others by the MICE (Modelling the Impacts of Climate Extremes) project and is used also for whole Europe (Bender and Schaller 2012). Referring to the 35 and $84.9 \mathrm{~mm}$ precipitation rate per day, extreme precipitation in Baden-Württemberg occurred mainly between 30 May and 1 June 2013 during the case study period.

In Germany, the highest hazard impacts and losses occurred in the catchments of the Danube and Elbe Rivers, with estimated total losses of at least 10 Billion Euro (Khazai et al. 2013). Although impacts in the southwestern state of Baden-Württemberg were less severe compared to the whole country, the state's road infrastructure was affected during this event. The scatter plot (Fig. 3) shows the number of hazardous incidents on roads in BadenWürttemberg. A total of 117 incidents led to traffic disturbances and road closures between 28 May (midnight) and 3 June (noon), more than one-fourth lasting more than $24 \mathrm{~h}$ (Table 2). In general, traffic disturbances tended to be shorter on federal freeways (German: Autobahnen) and federal highways (German: Bundesstraßen) than on state roads, about one-third of which were affected longer than $24 \mathrm{~h}$. Almost all of these incidents took place between the morning of 31 May and 3 June (Fig. 3). The peak with up to 45 incidents per hour was reached between 1 and 2 June.

Figure 3 shows a delay between the start, peak, and end of the precipitation and its impact on road infrastructure. The combination of precipitation rates and road incidents demonstrates that the delay between the extreme precipitation's onset and the increase of road incidents averaged 


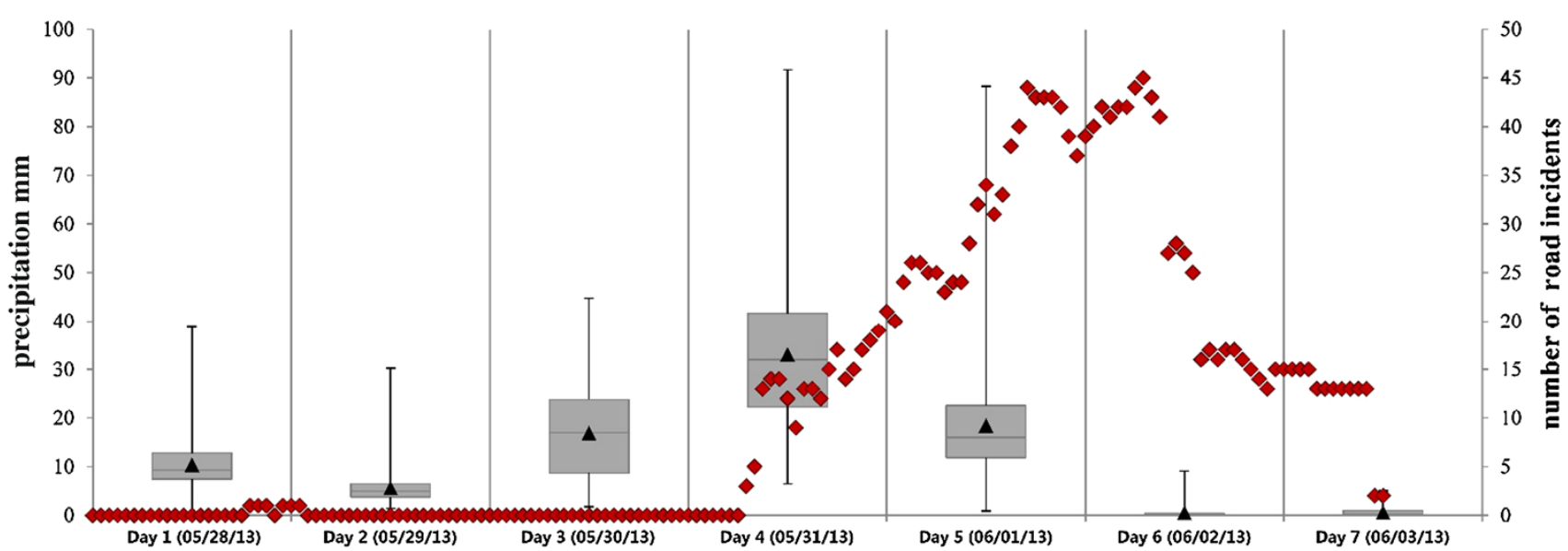

Fig. 3 Average daily precipitation rate (grey box plots) and number of road incidents (red scatter plot) in Baden-Württemberg, Germany, 28 May-3 June 2013. Source Graph by authors based on DWD REGNIE dataset 2013 and IMBW dataset 2013

Table 2 Duration of road incidents in Baden-Württemberg from 28 May to 3 June 2013 ( $n=117$ )

\begin{tabular}{|c|c|c|c|c|c|c|c|c|c|c|}
\hline \multirow[t]{2}{*}{ Duration } & \multicolumn{2}{|c|}{ All roads } & \multicolumn{2}{|c|}{ District roads } & \multicolumn{2}{|c|}{ State roads } & \multicolumn{2}{|c|}{ Federal highways } & \multicolumn{2}{|c|}{ Federal freeways } \\
\hline & Total & $\%$ of $n$ & Total & $\%$ of $n$ & Total & $\%$ of $n$ & Total & $\%$ of $n$ & Total & $\%$ of $n$ \\
\hline$\leq 3 \mathrm{~h}$ & 30 & 26 & 2 & 2 & 9 & 8 & 14 & 12 & 5 & 4 \\
\hline$>3-12 \mathrm{~h}$ & 34 & 29 & 7 & 6 & 11 & 9 & 8 & 7 & 8 & 7 \\
\hline$>12-24 \mathrm{~h}$ & 21 & 18 & 6 & 5 & 11 & 9 & 2 & 2 & 2 & 2 \\
\hline$>24 \mathrm{~h}$ & 32 & 27 & 8 & 7 & 17 & 15 & 6 & 5 & 1 & 1 \\
\hline
\end{tabular}

Source IMBW dataset 2013

Table 3 Types of weather-related road incidents in Baden-Württemberg from 28 May to 3 June $2013(n=117)$

\begin{tabular}{|c|c|c|c|c|c|c|c|c|c|c|}
\hline \multirow[t]{2}{*}{ Incident type } & \multicolumn{2}{|c|}{ All roads } & \multicolumn{2}{|c|}{ District roads } & \multicolumn{2}{|c|}{ State roads } & \multicolumn{2}{|c|}{ Federal highways } & \multicolumn{2}{|c|}{ Federal freeways } \\
\hline & Total & $\%$ of $n$ & Total & $\%$ of $n$ & Total & $\%$ of $n$ & Total & $\%$ of $n$ & Total & $\%$ of $n$ \\
\hline Traffic disturbance & 25 & 21 & 3 & 3 & 6 & 5 & 6 & 5 & 10 & 9 \\
\hline Closure (partial) & 10 & 9 & 0 & 0 & 1 & 1 & 3 & 3 & 6 & 5 \\
\hline Closure (complete) & 82 & 70 & 20 & 17 & 41 & 35 & 21 & 18 & 0 & 0 \\
\hline
\end{tabular}

Source IMBW dataset 2013

$12 \mathrm{~h}$. While the precipitation peak was reached on 31 May, the number of road incidents kept on increasing until 2 June, which was a precipitation-free day in the case study area.

In total, 92 incidents with road closures occurred during the study period accounting for around $80 \%$ of all incidents (Table 3). While road closures on federal freeways were unidirectional or limited to single lanes, federal highways were completely closed in more than 20 cases, two-thirds of them for more than one day. Around $70 \%$ of the road incidents were caused by flooding or flooding risk (Table 4). Due to higher speed limits, hydroplaning was mainly a problem on freeways and some federal highways. In total, hydroplaning accounted for $6 \%$ of all road incidents. Around one-fourth of all incidents were caused by landslides or landslide risks.

\subsection{Mapping of Spatiotemporal Hazard}

Figures 4 and 5 provide an overview of the spatiotemporal change of hazard patterns during the case study event. Both figures include five maps showing the daily precipitation rates for days 3-7. Days 1 and 2 are not included due to low precipitation rates and only one road incident. Figure 4 
shows secondary hazards like flooding or landslides that were triggered by the precipitation in locations with a specific disposition (De et al. 2004). Examples for locations with specific dispositions and the occurrence of natural hazards are described in Sect. 5. The natural hazards caused different types of road incidents as illustrated in Fig. 5.

In both figures, areas with high precipitation rates are highlighted in dark blue. The highest precipitation rates were generally found in the northern and southern parts of the Black Forest (south of Karlsruhe and Freiburg), in the center of the Swabian Alb (south of Stuttgart), in the Alpine foothills (east of Konstanz), and to a lesser degree in the north-eastern regions of Baden-Württemberg. The upper left maps (Figs. 4 and 5) show that on day 3, stronger precipitation set in in northern Baden-Württemberg with up to $50 \mathrm{~mm}$ near the northeastern state border. But no weather-related road incidents were reported on day 3.

This situation changed on day 4 with extreme precipitation rates exceeding $75 \mathrm{~mm}$ in the Black Forest between Freiburg and Karlsruhe, the Swabian Alb south of Stuttgart, and the Alpine foothills east of Konstanz (upper right maps in Figs. 4 and 5). By 9 a.m., 13 road incidents had occurred, reaching a maximum of 19 incidents that day (Fig. 3). Road incidents accumulated mainly in four regions (upper right maps in Figs. 4 and 5). North of the Black Forest around Karlsruhe, hydroplaning caused traffic disturbances on federal freeway A5 (A stands for Autobahn), and flooding and landslides led to disturbances and closures of state roads. In northeast Baden-Württemberg, flooding and landslides also caused traffic disturbances and road closures on federal highways and minor roads. While precipitation in this region was moderate on day 4 , it had already started on day 3. The outskirts of the Swabian Alb south of Stuttgart were affected by traffic disturbances on flooded federal freeway A8 and by road closures due to flooding on roads leading up to the Swabian Alb. The fourth area affected was federal highway B31 (B stands for Bundesstraße), running along Lake Constance in the
Fig. 4 Precipitation and spatiotemporal occurrence of road incidents according to underlying hazards in Baden-Württemberg, Germany, 30 May-3 June 2013. Source Maps by authors based on DWD REGNIE dataset 2013, IMBW dataset 2013, and Esri dataset 2005

southeast, that had already been affected by landslides earlier.

On day 5, precipitation rates, though still high, decreased (center left maps in Figs. 4 and 5). Heavy precipitation was concentrated in the northern Black Forest east and south of Karlsruhe, the Swabian Alb south of Stuttgart, and the Alpine foothills east of Konstanz. The number of road incidents reached a peak of 43 incidents by 6 p.m. (Fig. 3). Incidents included closures of federal freeways, federal highways, and other roads in the Rhine Valley and on the outskirts of the Black Forest around Karlsruhe, mainly caused by flooding and landslides. An increase in landslides and flooding also led to closures and disturbances along the Swabian Alb. A newly affected region was the central north of Baden-Württemberg with flooded and closed federal highways along the Neckar River. In northeast and southwest Baden-Württemberg, the number of incidents during day 5 remained stable, but a number of new landslides occurred in the southeast.

On day 6 (center right maps in Figs. 4 and 5), precipitation stopped in most parts of Baden-Württemberg, with low rainfall in the northeast. However, the number of road incidents still increased overnight. A new peak of 45 incidents was reached by 7 a.m. New disturbances and closures occurred on flooded federal highways along the Neckar River south of Stuttgart and east of Mannheim. Federal freeway A8 between Karlsruhe and Stuttgart was partially closed due to flooding and federal freeway A96 in southeast Baden-Württemberg was partially closed for a few hours due to a landslide. The number of road incidents on the outskirts of the Swabian Alb and the northern edges of the Black Forest remained stable.

The last day of the case study period, day 7, was nearly free of precipitation in Baden-Württemberg (lower left maps in Figs. 4 and 5). Most road incidents disappeared by

Table 4 Hazards causing road incidents in Baden-Württemberg from 28 May to 3 June 2013 ( $n=117$ )

\begin{tabular}{|c|c|c|c|c|c|c|c|c|c|c|}
\hline \multirow[t]{2}{*}{ Incident cause } & \multicolumn{2}{|c|}{ All roads } & \multicolumn{2}{|c|}{ District roads } & \multicolumn{2}{|c|}{ State roads } & \multicolumn{2}{|c|}{ Federal highways } & \multicolumn{2}{|c|}{ Federal freeways } \\
\hline & Total & $\%$ of $n$ & Total & $\%$ of $n$ & Total & $\%$ of $n$ & Total & $\%$ of $n$ & Total & $\%$ of $n$ \\
\hline Hydroplaning & 7 & 6 & 0 & 0 & 0 & 0 & 1 & 1 & 6 & 5 \\
\hline Flooding (risk) & 82 & 70 & 17 & 15 & 36 & 31 & 23 & 20 & 6 & 5 \\
\hline Landslide (risk) & 27 & 23 & 6 & 5 & 11 & 9 & 6 & 5 & 4 & 3 \\
\hline Other causes & 1 & 1 & 0 & 0 & 1 & 1 & 0 & 0 & 0 & 0 \\
\hline
\end{tabular}

Source IMBW dataset 2013 


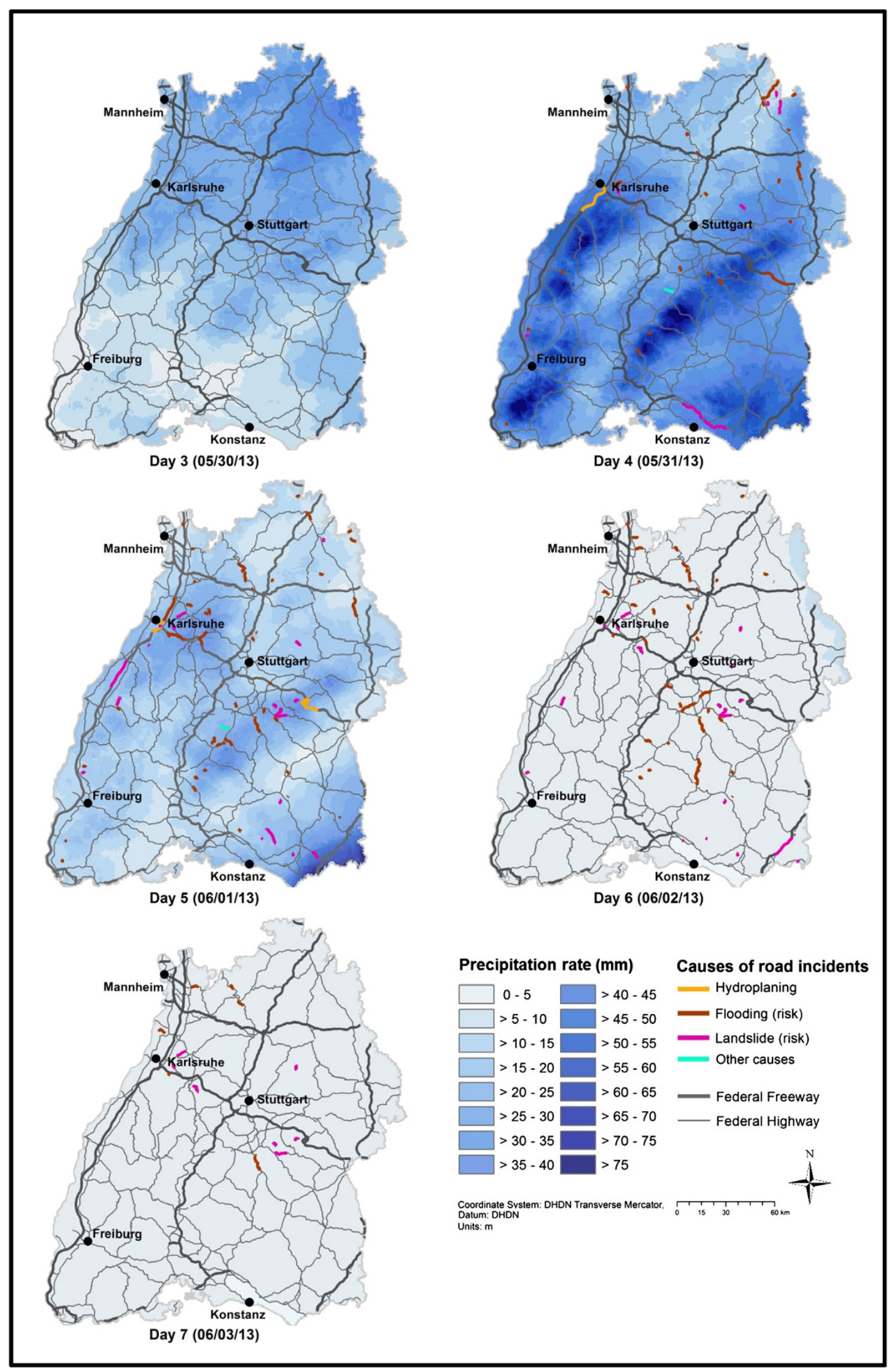




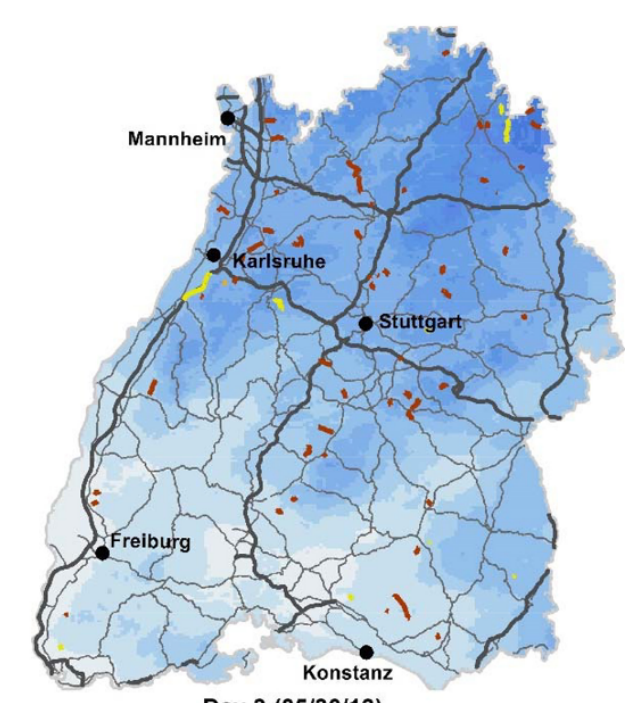

Day $3(05 / 30 / 13)$
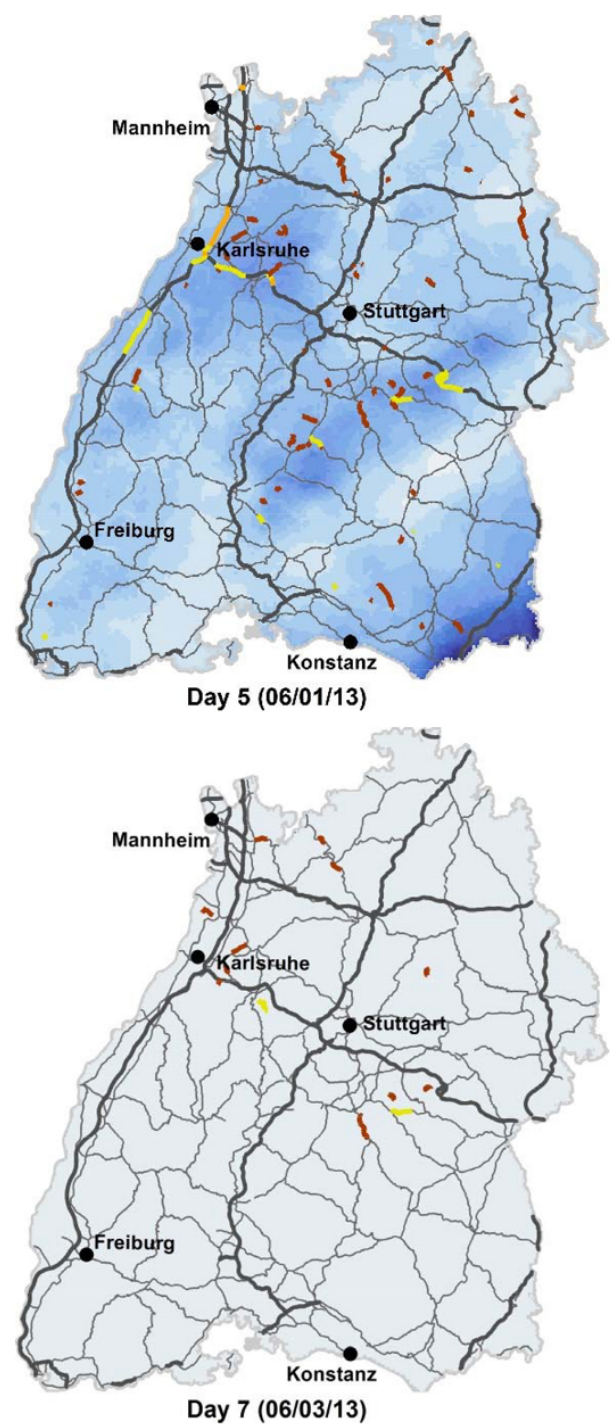

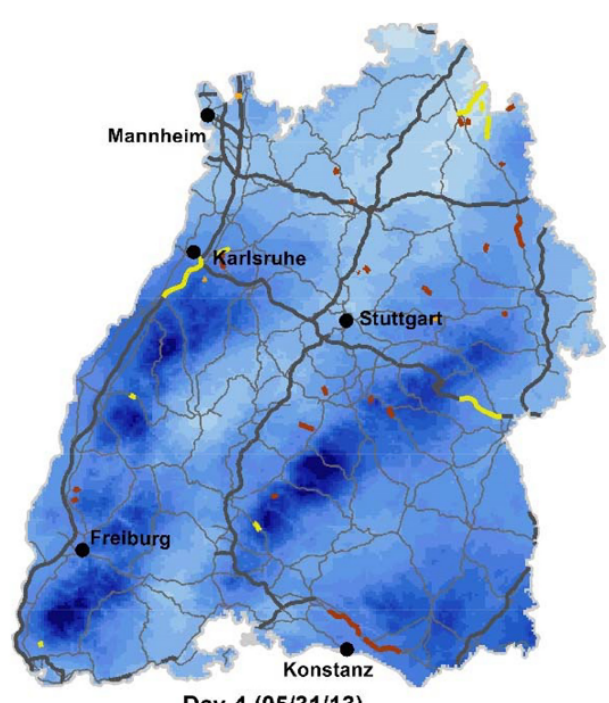

Day $4(05 / 31 / 13)$

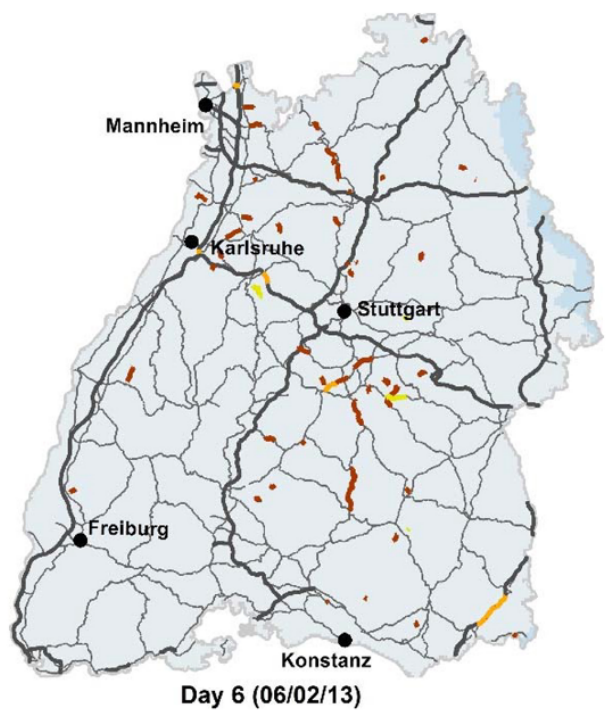

Precipitation rate $(\mathrm{mm}) \quad$ Types of road incidents

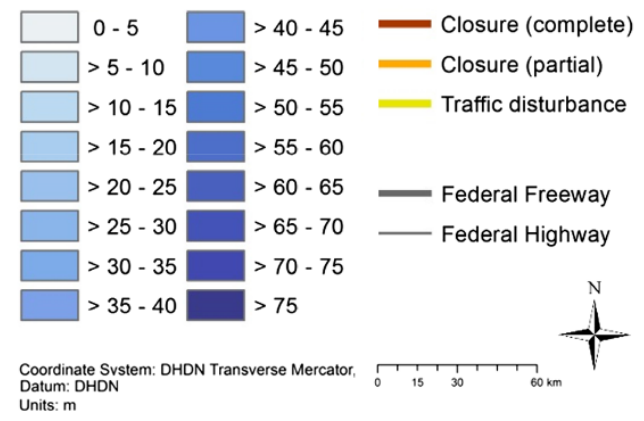


4Fig. 5 Precipitation and spatiotemporal appearance of different types of road incidents in Baden-Württemberg, Germany, 30 May-3 June 2013. Source Maps by authors based on DWD REGNIE dataset 2013, IMBW dataset 2013, and Esri dataset 2005

noon with 13 left at 10 a.m. and 2 incidents left at 11 a.m. (Fig. 3). The last incidents included flooded federal highways in the Neckar Valley east of Mannheim, minor roads around Karlsruhe, and roads on the northern border of the Swabian Alb. However, closures of roads leading up to the Swabian Alb lasted longer than the case study period.

\subsection{Spatiotemporal Patterns and Hazard Characteristics}

To clarify the spatiotemporal patterns on the basis of the above mapping, the hazards are characterized following the concepts developed by Egli (1996) and Bloetzer (1998), who define five natural hazard characteristics: limitation to specific locations; limitation to time; spontaneity; limitation to space; possibility to intervene.

The first characteristic is a hazard's limitation to a specific location with a specific natural setting (Egli 1996; Dikau and Glade 2002). The United Nations Report on Early Warning for Hydrometeorological Hazards (O'Neill 1997, p. 9) describes meteorological hazards as generally "highly mobile and trans-boundary in nature." Therefore, extreme precipitation, caused by a macro-weather situation or a regional weather cell, generally is not bound to specific locations. Egli (1996) describes meteorological hazards as being generally difficult to confine to a specific location.

Precipitation as the triggering meteorological hazard in this case study was of "medium limitation" to specific locations following Egli's (1996) characterization, namely the northern Black Forest, the Swabian Alb, and the southeastern Alpine foothills. The medium limitation results from the fact that the precipitation events did not occur in the whole area of Baden-Württemberg, which would translate to a low limitation. Additionally, the precipitation event occurred in many districts and affected large areas with different infrastructure. Therefore, the limitation is characterized as medium.

However, precipitation triggers infrastructure hazards only in hazard-prone locations. This is particularly true for landslides that involve a broad range of geomorphic processes and are highly dependent on specific locations (Dikau and Glade 2002). The extent to which flood events are limited in space depends on the altitude at which they occur (Egli 1996). Extreme and long-lasting precipitation and snow melting are among the factors that trigger floods.

The geomorphological situation in large parts of BadenWürttemberg is characterized by the South German Scarplands with alternating layers of resistant and soft, in some areas clayey, bedrock and steep slopes. This area is mainly drained by the Rhine and Neckar Rivers. Its specific geomorphology is at the root of three location types for road incidents. Firstly, incidents were clustered in areas with a high precipitation rate and steep slopes like on the northern fringe of the Swabian Alp, the western and northern fringes of the Black Forest, and the Alpine foothills. Secondly, incidents occurred along draining rivers such as in the Rhine Valley on the western state border, as well as the Neckar Valley in the Stuttgart region and east of Mannheim. Thirdly, incidents occurred in areas with clayey, soft soil layers such as in the areas northeast of Stuttgart.

The second characteristic, limitation to time, refers to specific temporal conditions that accompany the occurrence of hazards, such as seasons (Egli 1996). While precipitation may occur as a singular event without limitation to time, actual precipitation rates depend on seasonal conditions. Future changes of the precipitation regime due to climate change may increase the limitation to time.

Due to the high number of possible landslide-triggering events, landslides are hardly limited to a specific season. Furthermore, depending on the characteristics of a catchment area, the limitation to time of floods can vary.

In Baden-Württemberg, the situation differs between the Neckar and upper Danube catchment, where floods mainly depend on local precipitation, and the Rhine Valley, where floods are also possible in seasons with snow and ice melting in the upper Rhine catchment. This case study provides a typical example of a summer extreme precipitation event caused by the low Middle Europe weather situation.

Spontaneity is the third hazard characteristic. It includes both events with sudden impact and those beginning slowly as a creeping process (Egli 1996; Dikau and Weichselgartner 2005). The precipitation in this case study had elements of both. Longer periods of precipitation in April and May 2013 led to oversaturated soils creating an increased hazard disposition. The sudden extreme precipitation that occurred within 3 days between 30 May and 1 June 2013 was the triggering hazard. A characteristic extending spontaneity is the duration of hazards and their impacts on infrastructure. The time pattern for the case study period is shown in Fig. 3. The precipitation reached its peak in Baden-Württemberg on day 4, 31 May, while the number of road incidents kept on increasing until day 6 , 2 June. However, the decrease of precipitation rates in the first 2 days of June led to a normalization of road infrastructure functionality within a few days. When commuter traffic resumed on day 7, a Monday, most roads in BadenWürttemberg were functional again. Impacts on other parts of the transport infrastructure persisted for months because 
the floods in Eastern Germany had interrupted and destroyed important railway lines (DB 2013; VDV 2013).

The spontaneity of different types of mass movements ranges from permanent landslides to sudden movements (Dikau and Glade 2002). Given the high number of landslides that occurred during the period of extreme precipitation, it is reasonable to assume that they were mainly sudden movements triggered by precipitation. However, Baden-Württemberg has a number of locations that have been affected by landslides in the past and that have already been reactivated or run the risk of being reactivated in the future (Brodbeck 2012).

The fourth hazard characteristic is limitation to space, which describes the extent to which hazards and their impacts are concentrated in space. In general, the spatial impacts of extreme precipitation affect regions as well as global areas (Bloetzer 1998). The spatial impact of the "low Middle Europe" was high due to its stability over time (Khazai et al. 2013). Compared to other areas in Germany affected by the same extreme precipitation, floods in Baden-Württemberg were strongly limited in space. For instance, the floods in the Rhine catchment mainly affected the region hit by precipitation. In contrast, the floods occurring in the Elbe and Danube catchments concerned much larger regions. The spatial extent of precipitation impacts varied according to the precipitation rate along the course of the rivers and tributaries. Floodwater events may be either secondary hazards of extreme precipitation in a region, or secondary hazards of extreme precipitation upstream of a river. Overall, the Rhine catchment, which covers large parts of Baden-Württemberg, had lower flow rates in May and June 2013 than the catchments of the Danube and Elbe (Schröter et al. 2013). One major reason is that the upper catchment area of the Neckar, as the main tributary to the Rhine River, is situated in Baden-Württemberg. Thus, inflow from other regions with extreme precipitation remains low. While generally all types of landslides are characterized by a strong limitation to space (Egli 1996), in this case there was an obvious clustering of landslide-caused road incidents in the areas southeast of Stuttgart, northeast of Konstanz, and in the northeastern part of Baden-Württemberg (see upper right map in Fig. 4). Such clusters of small-scale hazards in one area can have similar effects on road infrastructure functionality as one larger-scale hazard in the same area.

The last characteristic is the possibility to intervene (Egli 1996). This explicitly excludes adaptive and other measures in the infrastructure or social system to avoid or reduce possible negative impacts of natural hazards. In contrast, Egli refers to the possibility of intervening at the root of a natural hazard in the natural environment system. With respect to extreme precipitation, this possibility is discussed in the context of climate change mitigation, but this goes beyond the scope of this case study. The possibility to intervene in the case of floods is limited to middleand long-term measures such as land use measures (Kalantari et al. 2014), as long as their aim is to improve the water retention capacity of a river that is at the root of flooding. If the land use change aims at leaving high-risk areas, it is adaptation. This example shows that the modification of underlying trigger processes, notably extreme events, is complex and not always easy to distinguish from adaptation (Egli 1996; Smith 2004). With respect to landslides, the possibility to intervene through measures at the hazard's root is limited. Protection measures include drainages and geotechnical constructions that change the rock movement processes (Smith 2013) to prevent rockfalls and shallow landslides. In contrast to changing these root causes, adaptation measures would be to accept mass movements in a certain area and change road alignment. Generally, large rockslides are difficult to stop by intervening at the root cause.

\section{Discussion: Results and Limitations}

Changing climate conditions unavoidably affect the characteristics and processes of natural hazards, which in turn affect infrastructure systems and the natural environment. In combination with the lack of structured information, this causal entanglement makes it difficult to define both areas at risk and the spatial distribution of natural hazards. Bloetzer (1998, p. 19), for example, points out the existing "uncertainty in estimating the present potential of natural dangers" for spatial planning. Analyzing and evaluating recent extreme events and natural hazards at different spatial and temporal scales contributes to reducing this uncertainty (BUWAL 1999; Adger et al. 2005; Bründl 2009). Therefore, this article proposes an explanatory hazard mapping approach based on observational design.

The physical impacts of the three hazard types that occurred on the road network of Baden-Württemberg during the extreme precipitation event in June 2013 were mapped in this study. The maps delineate the spatial and temporal hazard occurrence, their specific locations, and point out the influence of the meteorological trigger event on road infrastructure. Floods and landslides mainly occurred in areas with three specific characteristics: steep slopes, draining river valleys, and locations with soft and clayey rock layers.

Based on a single example of a specific natural hazard event, a specific infrastructure system, and a specific region, the results of this case study do not provide information on the seasonal appearance of extreme events, but highlight exemplary patterns of a summer precipitation 
hazard. Thus, the results only provide a first impression of linkages between infrastructure systems and their natural and social environment. The social and economic impacts of hazards in Baden-Württemberg need further investigation. Factors that need to be investigated include the road infrastructure criticality, road capacity and utilization, and the substitutability and types of traffic on affected roads at specific times. For instance, only few road incidents led to registered traffic delays. The most likely reason for this is that the hazard occurred on a long weekend. Thursday, 30 May 2013 (day 3) was a holiday, so it is reasonable to assume that fewer people went to work on the following Friday. Furthermore, precipitation stopped on Sunday. On Monday, when commuter traffic resumed, most road incidents disappeared by noon. It would be worth modeling how the same natural hazard would have influenced the social system on a normal weekday.

Hazard mapping based on spatiotemporal information is a basic tool to analyze processes within the framework of an integrated approach to natural hazards risk assessment (Chen et al. 2003). The parameters considered in this case study only reflect a fraction of those interesting and significant for integrated natural hazard risk assessment. But this study demonstrates that already a limited amount of information allows the deduction of basic patterns and linkages between the natural environment and infrastructure systems.

\section{Conclusion}

Further research is needed on the linkages between natural and social environments and infrastructure systems. Providing a broader image of hazard patterns and connections between the infrastructure system and its environments, the systemic, observation-based approach presented here complements experimental and material studies of climate change impacts on infrastructure systems.

The present case study provides an insight into patterns of precipitation hazard impacts on the road infrastructure in Baden-Württemberg. The issues examined are by no means exhaustive. Hazard mapping is a valuable tool in risk assessment analysis of climate change and natural hazards. By combining recent data on natural hazards and climate phenomena with their impacts on road infrastructure in a time series analysis, further possible changes in the occurrence and behavior of hazards may be predicted and represented in hazard maps. This approach promotes a broader, more integrated view on climate change and natural hazards that can be applied in spatial planning, disaster prevention and management, as well as in other research fields.
Open Access This article is distributed under the terms of the Creative Commons Attribution License which permits any use, distribution, and reproduction in any medium, provided the original author(s) and the source are credited.

\section{References}

Adger, N., N. Arnell, and E. Tompkins. 2005. Successful adaptation to climate change across scales. Global Environmental Change 15(2): 77-86.

Alcántara-Ayala, I. 2002. Geomorphology, natural hazards, vulnerability and prevention of natural disasters in developing countries. Geomorphology 47(2-4): 107-124.

Atzl, A., and S. Keller. 2013. A systemic approach for the analysis of infrastructure-specific social vulnerability. In From social vulnerability to resilience: Measuring progress toward disaster risk reduction, ed. S. Cutter and C. Corendea, 27-43. UNU-SOURCE 17/2013. Bonn: The United Nations University Institute for Environment and Human Security (UNU-EHS).

Atzl, A., J. Lerch, J. Luxen, B. Urban, and C. Lackner. 2012. Synopsis of selected risk reports from Germany, Europe and internationally (Synopse zu ausgewählten Gefahrenberichten aus Deutschland, Europa und international). Schriften der Schutzkommission 5. Bonn: Bundesamt für Bevölkerungsschutz und Katastrophenhilfe (in German, with English summary).

Auerbach, M., C. Hermann, and B. Krieger. 2014. Climate change and road infrastructure (Klimawandel und Straßenverkehrsinfrastruktur). http://www.vsvi-hessen.de/download/20140122/vsvi2 0140122auerbach.pdf (in German).

Becker, E., T. Jahn, and D. Hummel. 2006. Societal nature-relations (Gesellschaftliche Naturverhältnisse). In Soziale Ökologie, ed. E. Becker, and T. Jahn, 174-197. Frankfurt: Campus Verlag. (in German).

Bender, S., and M. Schaller. 2012. Comparative lexicon: Important definitions, thresholds, specifications and indices for questions concerning the issue "Climate change and its impacts" (Vergleichendes Lexikon: Wichtige Definitionen, Schwellenwerte, Kenndaten und Indices für Fragestellungen rund um das Thema "Klimawandel und seine Folgen"). Geesthacht: Climate Service Center Germany (CSC) (in German).

Bloetzer, W. 1998. Climate change and natural risks in spatial planning: Methodological approaches and examples (Klimaänderungen und Naturgefahren in der Raumplanung: Methodische Ansätze und Fallbeispiele). Zürich: vdf (in German).

Braubach, A. 2011. Vulnerability of the critical infrastructure for fresh water provision to natural disasters (Vulnerabilität der kritischen Infrastruktur Wasserversorgung gegenüber Naturkatastrophen). Forschung im Bevölkerungsschutz 12. Bonn: Bundesamt für Bevölkerungsschutz und Katastrophenhilfe (in German).

Brodbeck, M. 2012. Climate and slope kinematics on the example of the Großscholle landslide "Wildenberger Hang" (Klima und Hangkinematik am Beispiel der Großschollenrutschung "Wildenberger Hang”).” bast Straßenbau 2012 (S 76): 78-86 (in German).

Bründl, M. 2009. Risk concept for natural hazards - Guideline (Risikokonzept für Naturgefahren - Leitfaden). PLANAT (Swiss National Platform for Natural Hazards) (in German): Bern.

Burton, I., R. Kates, and G. White. 1993. The environment as hazard, 2nd ed. New York: Guilford Press.

BUWAL (Schweizerisches Bundesamt für Umwelt, Wald und Landschaft). 1999. Risk analysis for gravitative natural hazards: Cases and data (Risikoanalyse bei gravitativen Naturgefahren: 
Fallbeispiele und Daten). Umwelt-Materialien Nr. 107/II. Bern: BUWAL (in German).

Chen, K., R. Blong, and C. Jacobson. 2003. Towards an integrated approach to natural hazards risk assessment using GIS: With reference to bushfires. Environmental Management 31(4): 546-560.

DB (Deutsche Bahn). 2013. Restrictions in long-distance traffic of the German railway due to impacts of severe weather / floods (Einschränkungen im Fernverkehr der Deutschen Bahn aufgrund Unwetterfolgen / Hochwasser). http://www.bahn.de/blitz/view/ fernverkehr/uebersicht.shtml. Accessed 17 June 2013 (in German)

De, U., M. Khole, and M. Dandekar. 2004. Natural hazards associated with meteorological extreme events. Natural Hazards 31(2): 487-497.

Deutscher Bundestag. 2011. TA (Technikfolgenabschätzung) -project: Threat and vulnerability of modern societies on the example of a large-scale and long-term blackout: Report of the commission on education, research and technology assessment (TA-Projekt: Gefährdung und Verletzbarkeit moderner Gesellschaften am Beispiel eines großräumigen und langandauernden Ausfalls der Stromversorgung: Bericht des Ausschusses für Bildung, Forschung und Technikfolgenabschätzung). Drucksache 17/5672 (in German).

Dikau, R., and T. Glade. 2002. Dangers and risks of mass movements (Gefahren und Risiken von Massenbewegungen). Geographische Rundschau 54(1): 38-47 (in German).

Dikau, R., and J. Weichselgartner. 2005. The turbulent planet: Humans and the elements (Der unruhige Planet: Der Mensch und die Naturgewalten). Darmstadt: WBG (Wissenschaftliche Buchgesellschaft) (in German).

DWD (Deutscher Wetterdienst). 2009. Regionalized precipitation levels (Regionalisierte Niederschlagshöhen). http://www.dwd. de/bvbw/generator/DWDWWW/Content/Wasserwirtschaft/ Unsere_Leistungen/Hydromet_Info/Hydromet_Rasterwerte/ REGNIE_Infoblatt_pdf,templateId=raw, property=publication File.pdf/REGNIE_Infoblatt_pdf.pdf (in German).

DWD (Deutscher Wetterdienst). 2011. REGNIE (regionalized precipitation): Process description and user manual (REGNIE (REGionalisierte NIEederschläge): Verfahrensbeschreibung \& Nutzeranleitung). Offenbach: DWD (in German).

DWD (Deutscher Wetterdienst). 2013. June floods in the south and east of Germany (Juni-Hochwasser im Süden und Osten Deutschlands). News release. 2013. http://www.dwd.de/bvbw/ appmanager/bvbw/dwdwwwDesktop?_nfpb=true\&_pageLabel= dwdwww_menu2_presse\&T98029gsbDocumentPath=Content $\%$ 2FPresse\%2FPressemitteilungen\%2F2013\%2F20130606_Hoch wasserJuni_news.html. Accessed 10 June 2013.

Edwards, J. 1999. The temporal distribution of road accidents in adverse weather. Meteorological Applications 6(1): 59-68.

Egli, T. 1996. Flood protection and spatial planning (Hochwasserschutz und Raumplanung) Zürich: vdf (in German).

Eiser, J., A. Bostrom, I. Burton, D. Johnston, J. McClure, D. Paton, J. van der Pligt, and M. White. 2012. Risk interpretation and action: A conceptual framework for responses to natural hazards. International Journal of Disaster Risk Reduction 1(1): 5-16.

Etscheit, G. 2013. Levels as in the Middle Ages are possible (Pegel wie im Mittelalter möglich). http://www.zeit.de/gesellschaft/ zeitgeschehen/2013-06/bayern-hochwasser-wahl. Accessed 31 May 2013 (in German).

European Environment Agency. 2003. Mapping the impacts of recent natural disasters and technological accidents in Europe. Environmental issue report 35. Copenhagen: Office for Official Publications of the European Communities.

Felgentreff, C., and T. Glade. 2008. Natural risks and social disasters (Naturrisiken und Sozialkatastrophen). Berlin: Spektrum (in German)
Fürst, D. 2011. Political and administrative change (Politik und Verwaltung im Wandel). In Grundriss der Raumordnung und Raumentwicklung, edited by Akademie für Raumforschung und Landesplanung (ARL), 46-73. Hannover: ARL (in German).

Gares, P., D. Sherman, and K. Nordstrom. 1994. Geomorphology and natural hazards. Geomorphology 10(1-4): 1-18.

Gebhardt, H. 2008. Geography of Baden-Württemberg (Geographie Baden-Württembergs). Stuttgart: Kohlhammer (in German).

Geipel, R. 1992. Natural risks (Naturrisiken) Darmstadt: WBG (Wissenschaftliche Buchgesellschaft) (in German).

IPCC (Intergovernmental Panel on Climate Change). 2012. Managing the risks of extreme events and disasters to advance climate change adaptation. Cambridge: Cambridge University Press.

John-Koch, M., and A. Fekete. 2010. Protection of critical infrastructures - Also a municipal task (Der Schutz Kritischer Infrastrukturen - auch eine kommunale Aufgabe). In Drei Ebenen, ein Ziel: BEVÖLKERUNGSSCHUTZ - gemeinsame Aufgabe von Bund, Ländern und Kommunen, edited by BBK and Deutscher Städtetag, 22-29. Bonn: BBK (Bundesamt für Bevölkerungsschutz und Katastrophenhilfe) (in German).

Kalantari, Z., S. Lyon, L. Folkeson, H. French, J. Stolte, P.-E. Jansson, and M. Sassner. 2014. Quantifying the hydrological impact of simulated changes in land use on peak discharge in a small catchment. Science of the Total Environment 466-467: 741-754.

Khazai, B., T. Bessel, S. Möhrle, A. Dittrich, K. Schröter, B. Mühr, F. Elmer, T. Kunz-Plapp, W. Trieselmann, and M. Kunz. 2013. CEDIM FDA (Center for Disaster Management-Forensic Disaster Analysis) Report 2: Impacts and coping (CEDIM FDA Bericht 2: Auswirkungen und Bewältigung). http://www.cedim. de/download/FDA_Juni_Hochwasser_Bericht2.pdf. Accessed 31 May 2013 (in German).

Kreft, S., and D. Eckstein. 2013. Global climate risk index 2014: Who suffers most from extreme weather events? weather-related loss Events in 2012 and 1993 to 2012. http://germanwatch.org/de/ download/8551.pdf. Accessed 27 Aug 2014.

Lorenz, D. 2010. Critical infrastructures from the population's perspective (Kritische Infrastrukturen aus Sicht der Bevölkerung). Berlin: Freie Universität Berlin, Forschungsforum Öffentliche Sicherheit, Schriftenreihe Sicherheit Nr. 3 (in German).

Massey, D. 1999. Space-time, "science" and the relationship between physical geography and human geography. Transactions of the Institute of British Geographers 24(3): 261-276.

Minciardi, R., R. Sacile, and E. Trasforini. 2006. Assessing the efficiency and the criticality of the elements belonging to a complex territorial system subject to natural hazards. Natural Hazards and Earth System Science 6(1): 21-32.

Mitchell, J., N. Devine, and K. Jagger. 1989. A Contextual model of natural hazard. Geographical Review 79(4): 391-409.

Moss, T. 2011. Planning of technical infrastructure for spatial development: Requirements and challenges in Germany (Planung technischer Infrastruktur für die Raumentwicklung: Ansprüche und Herausforderungen in Deutschland). In Zukunftsfähige Infrastruktur und Raumentwicklung, edited by H.-P. Tietz and T. Hühner, 73-94. Hannover: ARL (Akademie für Raumforschung und Landesplanung) (in German).

O'Neill, D. 1997. Report on early warning for hydrometeorological hazards including drought. Geneva: United Nations International Strategy for Disaster Reduction (UNISDR).

Peterson, T., M. McGuirk, T. Houston, A. Horvitz, and M. Wehner. 2008. Climate variability and change with implications for transportation. Transportation Research Board of the National Academies. http://onlinepubs.trb.org/onlinepubs/sr/sr290Many. pdf. Accessed 31 May 2013.

Plate, E., and B. Merz. 1993. Natural disasters and disaster prevention (Naturkatastrophen und Katastrophenvorbeugung). Weinheim: VCH (in German). 
Ropohl, G. 2012. General system theory: Introduction to transdisciplinary thinking (Allgemeine Systemtheorie: Einführung in transdisziplinäres Denken). Berlin: edition sigma (in German).

Schramm, R. 2007. Storm front over Europe (Sturmtief über Europa) Bevölkerungsschutzmagazin (1): 35-37 (in German).

Schröter, K., B. Mühr, F. Elmer, T. Kunz-Plapp, and W. Trieselmann. 2013. CEDIM FDA (Center for Disaster Management-Forensic Disaster Analysis) Report 1: June 2013 flood in Middle Europe (CEDIM FDA Bericht 1: Juni-Hochwasser 2013 in Mitteleuro$p a)$. http://www.cedim.de/download/FDA_Juni_Hochwasser_ Bericht1.pdf. Accessed 31 May 2013 (in German).

Sherman, D., and K. Nordstrom. 1994. Hazards of wind-blown sand and coastal sand drifts: A review. Journal of Coastal Research Special Issue 12: 263-275.

Smith, K. 2004. Environmental hazards: Assessing risk and reducing disaster, 4th ed. New York: Routledge.

Smith, K. 2013. Environmental hazards: Assessing risk and reducing disaster, 6th ed. New York: Routledge.

Sobiech, C. 2013. Agent-based simulation of vulnerability dynamics. Heidelberg: Springer.

Temesgen, B., M. Mohammed, and T. Korme. 2001. Natural hazard assessment using GIS and remote sensing methods, with particular reference to the landslides in the Wondogenet Area, Ethiopia. Physics and Chemistry of the Earth, Part C: Solar, Terrestrial \& Planetary Science 26(9): 665-675.
UNISDR (United Nations International Strategy for Disaster Reduction). 2009. UNISDR Terminology: Disaster risk reduction. http://www.unisdr.org/files/7817_UNISDRTerminologyEnglish. pdf. Accessed 31 May 2013.

VDV (Verband Deutscher Verkehrsunternehmen). 2013. Flood impacts hit long-distance traffic (Hochwasserfolgen treffen Fernverkehr hart) VDV Das Magazin (September): 9 (in German).

Wagner, K. 2010. Climate change as a trigger of rapid change in natural risk management (Klimawandel als Auslöser eines rapiden Wandels im Naturgefahrenmanagement). In Climate Change (Der Klimawandel), ed. M. Voss, 363-376. Wiesbaden: VS (in German).

Welle, T., J. Birkmann, J. Rhyner, M. Witting, and J. Wolfertz. 2013. WorldRiskIndex 2013. In World Risk Report 2013, 45-56. Berlin: Alliance Development Works. http://www.worldriskre port.com/. Accessed 27 Aug 2014.

Weichselgartner, J. 2001. Disaster mitigation: The concept of vulnerability revisited. Disaster Prevention and Management 10(2): 85-95.

White, G., R. Kates, and I. Burton. 2001. Knowing better and losing even more: The use of knowledge in hazards management. Environmental Hazards 3(3-4): 81-92. 